\title{
Water storage in soils during the fallow: prediction of the effects of rainfall pattern and soil conditions in the Ebro Valley of Spain
}

\author{
R. B. Austin, E. Playán and J. Gimeno
}

Departamento de Genética y Producción Vegetal, Estación Experimental de Aula Dei, C.S.I.C., Apdo 202, 50080 ZARAGOZA, Spain

\section{Abstract}

Fallowing remains a feature of dryland cereal agriculture in some low rainfall areas of central and northern Spain. To complement the limited number of measurements of water stored during the fallow, we devised a physically based simulation model to estimate the effects of variations in rainfall, soil characteristics and surface conditions on water storage in the profile. Mean annual rainfall in the locations investigated varied from ca $300-500 \mathrm{~mm}$ and the mean amount of water stored during the last year of a bare fallow ranged from I-48 mm, depending on soil and climate. The standard deviations of these amounts, each based on 25 simulations, varied from II-39 mm. Rainfall in the last three months of the fallow was the principal cause of this year to year variation in storage. Surface stoniness and crop residues decreased evaporation from the soil and increased storage: there was very little drainage. These findings are consistent with measured water storage in soils in this part of Spain, and other areas of the world with similar climates and agricultural practices. Based on barley yield/rainfall regressions for data from a dry area in the Ebro valley, we estimated that the 
annual yields from a crop - fallow system would be $15 \%$ greater than those from annual cropping. For fallowing to be economic, yields per crop would need to be about twice those obtained with annual cropping. There may be yield benefits from fallowing apart from those resulting from extra water storage in the soil. Unless such benefits can be demonstrated, fallowing would appear to be unnecessary in this area of Spain.

Keywords: Fallowing; Rainfall; Soil water; Cereals

\section{Introduction}

Before the advent of tractor ploughing and the use of fertilisers and herbicides, fallowing was a widespread practice in many agricultural systems throughout Europe. Cultivation during the fallow facilitated weed control, and the oxidation of soil organic matter increased the amount of nitrogen readily available to the following crop. For some soils, fallowing was necessary before the land could be cultivated. In areas where the production of annual crops was limited by shortage of water, as in much of Spain, fallowing (cultivo de año y vez or cereal-fallow rotation) was thought to increase the amount of water stored in the soil and available to the succeeding crop. The extra soil moisture was considered to benefit yield but, probably of greater importance in rainfed subsistence agriculture, to considerably reduce the risk of crop failure.

In modern agriculture, chemicals are used for weed control and mineral fertilisers supply most of the crop's needs for the major nutrients. Accordingly, fallowing is now rarely used in the relatively humid areas of northern Europe. In water limited areas, fallowing 
can be justified if the benefits to yield from the extra water stored in the profile at least compensate for the reduction in the time-averaged yield (one crop in two years, compared to one crop each year) and/or if pests and diseases are better controlled than in continuous cropping.

In water limited areas, the amounts and distribution of rain are very variable in time and space. Also, there is great variability in soil characteristics and soil depth. For these reasons, it is very expensive and time consuming to assess the amounts of water stored in the soils of a given area and how the amounts vary with rainfall and soil type. In areas of the world with summer rainfall, and/or where the soils are deep and can retain much water, fallowing has been shown to substantially increase the amount of water available to the following crop, making arable cropping feasible (as in some parts of the Great Plains of the U.S.A.; Ramig et al., 1983). In the countries of the Mediterranean basin, although fallowing is still practised, the benefits, in terms of water stored and increased crop yields, are likely to be quite small, because the soils are generally shallow and the summers are very dry and hot. In the cereal growing areas of northern and central Spain (Castilla y León, Castilla La Mancha, Aragón) and Cataluña the distribution of rain is much more uniform through the year, though with minor peaks in April-May and October-November. The principal rainfed crop grown is barley, and the average yield is ca $1.8 \mathrm{t} \mathrm{ha}^{-1}$. In the drier of these areas, particularly in the Monegros region of central Aragón, fallowing is still widely practised. However, in a study in central Aragón, López et al. (1996) found that the water stored in the soil to a depth of $80 \mathrm{~cm}$ during the long fallow varied between $-4 \mathrm{I}$ and $+58 \mathrm{~mm}$, with an average over locations and cultivation treatments of only $12 \mathrm{~mm}$. 
We devised a physically-based simulation model for calculating the amounts of water stored in the soil profiles and have used it to assess the amounts likely to be stored in soils of varying characteristics, in climates with different amounts and variable patterns of rainfall. A somewhat similar model to ours (López and Giráldez, 1992) has been used by its authors to explore water storage in soils during the fallow in the climatic conditions of Córdoba, Spain, in an area with a typically Mediterranean climate and rainfall pattern.

We compute the water stored in the soil as a consequence of a fallow as the difference between (a) that present immediately before sowing a cereal crop (typically I December in central Aragón), and (b) that which is present one year before, after the minimum fallow of ca 5 months (from harvest in June to sowing in the following December). We have used this definition as it does not require the water content of a cropped soil to be known, and so is a function only of soil characteristics, including initial water content, and the weather.

\section{Materials and methods}

\section{The model}

The simulation model, written in FORTRAN 77, contains coding to simulate rainfall, evaporation from the soil surface and the movement of water among defined layers in the soil including drainage from the soil profile. These components of the model are described below. 
Simulation of rainfall. A two state, first order Markov chain model is used to determine whether it will be wet or dry on a given day. Two transitional probabilities are needed for this model. The first is the probability that tomorrow will be wet if today is dry $\left(p_{\text {wd }}\right)$ and the second is the probability that tomorrow will be wet if today is wet $\left(p_{\text {ww }}\right)$. Geng et al. (1986) showed that these two probabilities could be estimated given the fraction of rainy days (FRD) in a period from:

$$
\begin{aligned}
& P_{w d}=0.75 \text { FRD } \\
& p_{w w}=0.25+p_{w d}
\end{aligned}
$$

Since monthly summaries of rainfall records are available for many locations, FRD was readily obtained from these records.

To simulate the rainfall amount on a rainy day, a single parameter, calibrated Weibull distribution described by Selker and Haith (1990) was used. The rainfall, $x$, on a given rainy day was calculated from:

$$
x=c \mu(-\ln r)^{1 / 0.75}
$$

where $r$ is a random number with uniform distribution, in the range $0-I$, and $\mu$ is the mean precipitation per rainy day. Values of $\mu$ for each month were obtained from summaries of long term rainfall records. The value of $c$ was taken as 0.9 . With this value, rainfall at the locations in the Ebro valley was simulated more accurately than with Selker and Haith's value of 0.84 , which had been optimised for many sites. 
Estimates of the two parameters needed to simulate daily rainfall, $F R D$ and $\mu$, were obtained from long term records of five stations in the Ebro valley and from Córdoba in Andalucía. For each location, the mean monthly values of these parameters were used so that seasonal changes in the amounts and distributions of rainfall could be simulated. As a simplification for programming, rain during a day was taken to be uniformly distributed throughout the $24 \mathrm{~h}$ of the day.

Evaporation from the soil surface. Evaporation from the surface $(E)$ was described empirically by a function of the current day's reference evapotranspiration (ETo) and the gravimetric water content $(w)$ of the soil. The relationship was determined for four soils subjected to four surface treatments using a microlysimeter method (Boast and Robertson, 1982). For this, a layer of surface soil $50 \mathrm{~mm}$ deep was placed in a polyethylene tray $(50 \mathrm{x}$ $25 \times 10 \mathrm{~cm}$ deep), watered to saturation and weighed. The tray was then placed into moist soil so that the soil surfaces inside and outside the tray were coincident. Subsequently, at intervals varying from ca I h to I day, the tray was removed from the soil and reweighed. The ETo during each interval was calculated by the Penman-Monteith method (Allen et al., 1994) at 30 min intervals. The mean soil moisture content during each interval was calculated from the weights, and the relationship between soil moisture content and the ratio of $E$ to ETo, EETo, was determined.

Experiments were performed for the four soils and four surface treatments, using three replications. The experimental approach used to characterize evaporation is very well suited to explore the relationship between EETo and soil surface conditions. One of the 
considered surface treatments was bare soil (labelled BA). Two of them involved surface stoniness, and were characterised by a $30 \%$ or $60 \%$ coverage of the surface. The low and high stoniness treatments were labeled as $\mathrm{SL}$ and $\mathrm{SH}$, respectively. The last treatment was characterised by a coverage with crop residues (CR) corresponding to $2,500 \mathrm{~kg} \mathrm{ha}^{-1}$ of barley straw. It was found that a Gompertz model described the relationship well for all treatments, accounting typically for ca $80-90 \%$ of the variance in EETo. The fitted model was :

$$
\mathrm{EETo}=\frac{E}{\mathrm{ETo}}=P 1 \exp \{-\exp [-P 2\langle w-P 3\rangle]\}
$$

where $P I, P 2$ and $P 3$ are empirical coefficients. The relationship was used to compute daily EETo using the actual soil water status and an estimate of mean daily ETo. Monthly evapotranspiration was computed for this purpose at each site using a locally calibrated FAO release of the Blaney-Criddle equation (Faci et al., 1994). Examination of long term weather records from the chosen sites showed that ETo on rainy days was on average 0.75 times that on dry days. To allow for the effect that this would have on evaporative losses from the soil on wet days, the ETo on a rainy day was taken to be 0.75 times the mean monthly ETo, while that on dry days was increased by a factor which took into account the fraction of rainy days in the month so that the mean ETo for all days of the month was the same as that specified in the climatic input.

Water movement in the soil and drainage. For the purpose of simulation, the soil was divided into layers. The Brooks-Corey equations (Brooks and Corey, 1966) were used to compute unsaturated water flow between layers. The variable saturation $(S)$ is defined as : 
where $\theta$ is the volumetric water content of the soil and $\theta_{s}$ is the saturated volumetric water content. Next, effective saturation $\left(S_{e}\right)$ is defined as :

$$
S_{\mathrm{e}}=\frac{S-S_{r}}{1-S_{\mathrm{r}}}
$$

where $S_{r}$ is the residual saturation of the soil. The matric potential of the soil water $(\Psi)$ can be expressed as :

$$
\psi=P_{\mathrm{b}} S_{\mathrm{e}}^{\frac{-1}{m}}
$$

where $P_{b}$ is the bubbling pressure of the soil and $m$ is the pore distribution coefficient.

Subsequently, the hydraulic conductivity of the soil $(K)$ can be computed as a function of soil water :

$$
K=K_{\mathrm{s}} S_{\mathrm{e}}^{\frac{2+3 m}{m}}
$$

where $K_{s}$ is the saturated hydraulic conductivity.

In the model, elevation and matric potential are supposed to be the only components of the hydraulic head. Under these conditions, water flow between two contiguous layers ( $i$ and $i+I)$ and between time steps $j$ and $j+I$ can be approximated as : 


$$
Q_{i, i+1}^{j, j+1} \approx \frac{K_{i}^{j}+K_{i+1}^{j}}{2} \frac{\psi_{i}^{j}+\Delta z-\psi_{i+1}^{j}}{\Delta z}
$$

where $\Delta \mathrm{z}$ is the layer thickness. This approximation permits unsaturated flow in both directions (upwards and downwards) and explicit computation throughout the soil profile. Proper boundary conditions must be expressed at the upper and lower layers. Evaporation, as discussed previously, and precipitation, are the considered boundary fluxes for the surface layer. Both processes are supposed to be uniformly distributed during a given day. At the lowest layer, drainage flow is computed following the assumption of a unit (gravitational) gradient. This approximation implies constant water content in depth below the lower boundary layer.

Each soil is characterised by a set of layers and associated properties. Layer thickness is adjusted to produce agreement between layers and soil horizons. Thin layers can be set in the upper part of the profile, where transients in hydraulic properties are expected to be larger than in lower layers. For consistency with the evaporation data the upper layer is always $50 \mathrm{~mm}$ thick. In the lower layers of the profile, a $100 \mathrm{~mm}$ thickness was generally used. The effective depth of the soil profile is limited by soil depth or by the depth of the rooting system. For barley grown under semiarid conditions, the rooting depth was taken as $100 \mathrm{~cm}$ (except in the shallow Canós UP soil - see below). Storage computations were performed for the layers within this effective soil depth. Water flowing below the effective soil depth was considered as drainage. All simulations started on I July. This is representative of the normal harvesting date of barley and the beginning of the fallow period. 
At this time, soil water has been completely extracted by the crop, and wilting point $(\Psi=$ $\mathrm{I}, 500 \mathrm{kPa}$ ) was taken as the initial condition for all layers.

The length of the time step is under program control, depending on the amount and closeness of recent precipitation events and on soil parameters. In the data we presented the time step varied from $0.1 \mathrm{~min}$ to I day. Larger time steps are used during quasi-steady-state periods and for soils with high water retention capacity. Mass conservation is verified daily in the model, by computing the water balance error as a percentage of cumulative precipitation. Generally, this error was less than $0.1 \%$.

\section{Characterisation of the climates studied}

Five climatic locations were selected in the Ebro valley, four in Aragón and one in Cataluña. The summary of long term records (Table I) shows that yearly precipitation ranges among sites, from a minimum of $326 \mathrm{~mm}$ in Montañana to a maximum of $485 \mathrm{~mm}$ in Monflorite. For comparison with the locations in the Ebro valley, we used data from Córdoba (Andalucía) which has a typical Mediterranean climate, with a unimodal rainfall distribution and virtually no rain during July - August. Córdoba also has more rain, with a long term mean of $635 \mathrm{~mm}$. Evapotranspiration estimates (Faci et al., 1994) are remarkably similar for all six stations, with an average of $\mathrm{I}, 094 \mathrm{~mm}$.

Monthly precipitation (Fig. Ia) shows a bimodal pattern in the Ebro valley sites, with peaks in April - May and September - October. The fraction of rainy days (FRD) follows a 
similar trend (Fig. Ib), except that in the Ebro valley sites FRD remains high during winter, indicating the occurrence of frequent, small precipitation events.

\section{Characterisation of the soils studied}

Four soils were characterised. They are representative in terms of their physical properties of those on which cereals are grown in the Ebro Valley. The first soil profile, EEAD, is a silt loam classified as a Typic Torrifluvent. EEAD is located at the experimental farm of the Aula Dei research station in Montañana (Zaragoza). It is a deep, alluvial soil. Canós UP and Canós LO are silt loam soils located in El Canós (Lleida). Canós UP is a Typic Xerorthent located on an upper geomorphological unit heavily affected by erosive processes. The soil is shallow and rests on a fractured horizon of carbonated rock. Canós LO is a Fluventic Xerochrept. It is located in a lower unit characterised by deposition and the profile is therefore deeper and uniform. The fourth soil, Vedado, is a silt loam Xerollic Calciorthid. It is from El Vedado, an experimental farm of the Government of Aragón in Zuera (Zaragoza).

All four soils were sampled to determine the soil physical properties. Samples were collected by horizons from the entire profile, or to a depth of $150 \mathrm{~cm}$ where the soil was deeper than $150 \mathrm{~cm}$. Standard methods of soil physics analysis were used to obtain the required parameters for each soil (Table 2). Matric potential was determined using pressure plates. A disc permeameter was used to perform in situ measurements of the saturated hydraulic conductivity of each soil (Perroux and White, 1988). 


\section{Results}

\section{Simulation of rainfall}

Table 3 summarises the characteristics of the actual and the simulated annual rainfall for four locations which contrast in the rainfall amounts and their distributions. The amounts and distributions of rainfall over months, which were also well simulated (data not shown) will clearly influence water storage in soils. Water storage is also critically dependent on whether the rain falls mainly in light showers or as heavy storms. Table 3 shows two measures of the distribution of rainfall amounts, and that the actual distributions were well matched by the simulated data. A further comparison (data not presented) showed that the distribution of lengths of dry periods was also adequately simulated.

\section{Evaporation of water from the soil surface}

The experimental values of EETo did not allow separation between the studied soils, as shown by the scatter plot for all four bare soils (Fig. 2). The fitted Gompertz curve is the average response for all soils of EETo to changes in $w$. The experimental data are consistent with the three-phase model of the evaporation process described by Gardner (1983). The evaporation rate is high and constant when the soil is humid, decreasing as it dries out and is low and constant when the soil is dry and adsorptive forces regulate the soil-water interphase. It should be noted that in the model the independent variable is not time but the soil water content. The choice of $w$ as the independent variable adds generality to our model and so was used instead of time. The regression curves corresponding to each 
surface condition studied are presented in Fig. 3. EETo decreases with surface treatments: bare soil $>30 \%$ stoniness $>60 \%$ stoniness $>$ crop residue cover. A similar effect of crop residues was described by Bussière and Cellier (1994). The effect of stoniness seems to be due mainly to the reduction in the evaporative surface. Table 4 presents the set of parameters corresponding to each surface treatment.

\section{The effects of soil type and depth}

As noted in the introduction, we argue that the benefit of a fallow year in the Ebro valley is most appropriately calculated as the difference between that present in the profile at the normal sowing time (taken as I December) and that present one year earlier. If there was no fallow year, the minimum fallow, when the soil would be bare, would be approximately five months (harvesting of a previous crop in June to sowing of the next crop in early December). Significant recharge of the profile is likely to occur during the autumn of this period (depending on the rainfall), when ETo is low and autumn rains have begun. Because our calculations exclude the effects of recharge during this 'minimum' fallow, our estimates of water storage attributable to the fallow year are conservative.

The change in water content during the minimum fallow period can be derived from the data in Table 5 as that present in the soil on I December and that present at the start of simulation on I July ( $148-142=+6 \mathrm{~mm}$ in the case of the Vedado soil and the Montañana climate). It should be noted, however, that the soil water content at the start of simulation was set to be at permanent wilting point. We believe that this will generally be a close approximation to reality. Because of the importance of autumn and winter rains for soil 
water storage, the mean and variation in the water content at the start of the fallow year on I December will be influenced mainly by precipitation during the imediately preceeding two months, October and November. This can also be seen from Fig. 4 which shows (for Canós LO soil and Montañana climate) that after continued drying out of the profile during July and August, soil water is gradually recharged until the following February, when it contains ca $210 \mathrm{~mm}$ water. This water content is not achieved subsequently until the end of the following October in this example and the net increase occurs mainly in the last month of the fallow, resulting in a mean net storage during the fallow year as we define it of only $25 \pm$ $31 \mathrm{~mm}$ (Table 6).

Storage in the shallow profile (Canós UP) was negligible and in Vedado it was also small. Only in deep soils, well graded soils (Canós LO and EEAD) was the average storage appreciable, generally 30 - $50 \mathrm{~mm}$ (Table 6).

\section{Effects of climate}

The sites in the Ebro valley ranged in mean rainfall from 326 - $485 \mathrm{~mm}$ (Table I), and differed little in the monthy distribution of this rain (Fig. Ia), though Candasnos and Montañana had fewer rainy days than the other sites (Fig. Ib). For a soil with a good water storage capability (Canós LO), the actual storage averaged over 25 runs was related to the mean simulated rainfall at that site $(r>0.9)$. However, as a percentage of the mean rainfall during the 365 day fallow period, mean storage among the sites in the Ebro valley was within the range $7.0-9.5 \%$. The corresponding evaporation from the soil ranged from $87-92 \%$ 
of rainfall (Table 7). Accordingly, drainage was very small, ranging from $0.7-3.4 \%$ of rainfall.

In Córdoba (Andalucía), the climate is typically Mediterranean, with a markedly unimodal rainfall distribution, as noted earlier (Fig. Ia). With the climatic data for Córdoba, and the Canós LO soil, we found that mean water storage was $72 \pm 64 \mathrm{~mm}$ during the fallow year, the corresponding simulated mean rainfall being $663 \mathrm{~mm}$ (Table 8). Storage was thus $10.8 \%$ of the rainfall during the period, and drainage $137 \mathrm{~mm}$. The corresponding results for the wettest location in the Ebro valley (Monflorite) were: storage $48 \pm 39 \mathrm{~mm}$; rainfall $507 \pm 82 \mathrm{~mm}$ (storage $9.5 \%$ of rainfall) and drainage $17 \mathrm{~mm}$ (Table 8).

\section{Effects of soil surface conditions}

These effects were explored for the Canós LO soil and the climate of Montañana. A stony surface or straw cover increased the water content at the start of the fallow period and the additional water stored during the fallow period, with corresponding reductions in evaporation (Table 9) and very small increases in drainage. The maximum improvement in water storage was obtained with straw cover $(23=48-25 \mathrm{~mm}$, Table 9), but this improvement only amounted to $6.8 \%$ of the rainfall.

\section{Year-to-year variation in water storage}

Water storage in the soil was strongly influenced by precipitation. This is illustrated in Fig. 5 for the EEAD soil and the Montañana climate. Fig 5a shows storage during the 17 
months from harvesting of the previous crop to sowing of the following one plotted against rainfall during the same period. Fig. 5 shows that the temporal distribution of the rain during this 17 month period had a very large effect on storage, which ranged from ca 30 to $120 \mathrm{~mm}$. This variation was mainly due to year to year variation in the distribution of rainfall during the last six months (June - November, inclusive) of the last year of this period (Fig. 5c cf Fig. 5b), especially that in September, October and November (Table 10).

As expected, most water is stored in the lower part of the profile. The storage can be seen from Fig. 6 as the difference between the water content at day 334 of the simulation, and that at day 708 . This interval corresponds to the last year of the 17 month fallow. However, as can be seen from the bars indicating the standard deviation (based on 25 simulations), the water content of the surface layers varies greatly over years. This reflects the variation in rainfall during the last few months of the fallow (see also the previous paragraph).

\section{Discussion}

The average amounts of water stored during the last year of the fallow for the simulations in the Ebro basin ranged from I to $48 \mathrm{~mm}$ depending on soil and climate (Table 6). Excluding the shallow soil, Canós UP, the mean storage averaged across soils and climates was $27 \mathrm{~mm}$. As shown in Fig. 4 and Table 10, the amount of storage was determined principally by the rainfall in the three months before the end of the fallow (September - November inclusive). This conclusion is supported by the results shown in Fig. $5 c$, although storage is significantly influenced by the rainfall in the first six months of 
the last year of the fallow (Fig. 5b). As expected, the increase in the soil water content during the entire 17 month fallow (harvest of the previous crop to sowing of the next one) was significantly correlated with the total rainfall during the period (Fig. 5a). These relationships may also be demonstrated by multiple regression of the rainfall during the first five months of the fallow $\left(x_{l}\right)$ and that during the last twelve months $\left(x_{2}\right)$ on the water content of the profile at sowing. The corresponding coefficients are $b_{1}, 0.1920 \pm 0.0593, t=$ 3.24 and $b_{2}, 0.284 \mathrm{I} \pm 0.0493, t=5.76$. Thus, on average, for every $\mathrm{I} \mathrm{mm}$ of rain during the last year of the fallow $0.28 \mathrm{~mm}$ would be stored in the profile. During the first five months, $0.19 \mathrm{~mm}$ would be stored per I $\mathrm{mm}$ of rain.

The estimates of storage derived from these simulations are consistent with the necessarily limited number of experimental determinations of the water stored in soil profiles under the conditions in the Ebro basin. López et al. (1996) found that storage ranged from $-4 \mathrm{I}$ to $+58 \mathrm{~mm}$ (average $12 \mathrm{~mm}$ ) during a period which was generally drier than average. Our estimates are less than the storage measured in the Great Konya basin, Turkey, which was estimated by Janssen (1972) to be ca. $80 \mathrm{~mm}$ (but for profiles which were $200 \mathrm{~cm}$ deep). Our estimates are comparable with those given by Lawrence et al. (1994) over a four year period in Queensland (average storage $67 \mathrm{~mm}$ to a depth of $100 \mathrm{~cm}$ for an annual rainfall of ca. $600 \mathrm{~mm}$. Also in Queensland, Radford et al. (1992) estimated water storage to be the equivalent of $52 \mathrm{~mm}$ per $100 \mathrm{~cm}$ profile depth. Unger (198I) gives values obtained in Texas which are closer to our estimates (the equivalent of $31 \mathrm{~mm}$ per $100 \mathrm{~cm}$ of profile for a rainfall of ca $380 \mathrm{~mm}$ ). In the semi-arid area of Lethbridge, Alberta, Larney et al. (1995) estimated water storage of $50 \mathrm{~mm}$ per $100 \mathrm{~cm}$ of profile. French (1978) reported storage of $28 \mathrm{~mm}$ during a 9 - 10 month fallow in South Australia, for profiles 120 
$\mathrm{cm}$ deep. Except for the data from Janssen (1972), the above results are averaged over the various tillage systems investigated. Since some of the systems increased water storage (as in our results based on the microlysimeter tests - Table 9), it may be expected that the measured amounts of water stored reported in the studies will generally be greater than the values in our Table 6, which are for cultivated bare soil.

We do not suggest that the comparison of the measured values in the Ebro basin with our simulated values constitute a validation of the model. However, our model is physically based, and we believe the results of the simulations are a close reflection of reality. Possible sources of error in the model are that the effects of temperature on soil properties and processes are not explicitly modelled. The principal effect of temperature, is we believe, likely to be on evaporation from the soil surface. This effect of temperature has implicitly been allowed for in our equation 3 (see also Figs 2 and 3), which relates the ratio [actual evaporation from the soil surface: ETo] to the moisture content of the upper layer of the profile, because temperature has a direct effect on ETo. This equation allows the effects of soil type and soil surface condition to be characterised and the consequences for water storage in the profile to be determined.

Except where otherwise noted in the results, we assumed bare soil, maintained cultivated, without weeds. Further, we assumed that soil physical characteristics remained the same for a given soil throughout the entire fallow period, and were unaffected by rainfall. In reality, it is likely that the surface characteristics would change as the soil gradually became compacted so increasing bulk density, and after rainstorms which could cause crusting of the 
soil surface. Soil surface conditions as affected by the presence of stones or crop residues had the expected effects on water storage, straw cover almost doubling it (Table 8).

The management of fallowed land in the Ebro basin varies considerably with year and farm size and type. Commonly, after harvest the land will remain uncultivated until the following January or February. Then, it will be mouldboard ploughed or disked and will subsequently be kept weed-free until the end of the fallow by further disking or harrowing. For most of the last year, therefore, and certainly for the critical last months of the fallow, the surface condition of most soils will approximate to that of the bare soil simulated in the microlysimeters we used for determining water loss from the soil surface. Cultivation during fallow mixes the soil and increases moisture of the upper layer, thus increasing evaporation. This effect of cultivation has not been evaluated in our model.

The principal objective of this study was to provide information for assessing whether long fallowing as practised in the Ebro valley is beneficial to crops, in terms of moisture storage. Table 6 shows that, in general, the standard deviation of water storage was similar to mean storage. This means that in about $30 \%$ of the years, the soil water content at the end of the fallow would not have increased, or would have decreased as a consequence of the fallow. As noted, the average storage was ca. $27 \mathrm{~mm}$. These results suggest that the benefits from fallowing, in terms of water storage, are likely to be quite small. Regression of seasonal rainfall on barley yields for 50 years (unpublished data) for a location in the Monegros, showed that barley yield increased by ca. $9 \mathrm{~kg} \mathrm{ha}^{-1}$ per $\mathrm{mm}$ of rain in the three months after sowing. Accordingly, $27 \mathrm{~mm}$ of water stored would give a yield increase of $243 \mathrm{~kg} \mathrm{ha}^{-1}$. This value of $243 \mathrm{~kg} \mathrm{ha}^{-1}$ is ca $15 \%$ of the estimated average yield of barley in 
Zaragoza province (1600 kg ha ${ }^{-1}$ during 1987-1993). On this basis, fallowing seems unlikely to be as productive as annual cropping (i.e., considering benefits from water storage alone). However, fallowing can decease the incidence of some pests and diseases which may be difficult and expensive to control by other means. The nematode Heterodera avenae can cause severe yield loss in wheat and barley, particularly in coarse textured soils. It is present in Spain (López-Fando and Bello, 1995) and in El Vedado. Fallowing reduces the population of $H$. avenae (Amir and Sinclair, 1996), which otherwise would cause major loss of yield. Further study is needed to assess whether fallowing in this area of Spain maintains populations of $H$. avenae low enough to prevent significant yield loss from this parasite.

As noted, rainfall during the last months of the fallow (September - November, inclusive) is the principal determinant of the amount of water stored in the profle. This suggests that in years with wet autumns, farmers should sow without fallowing (i.e. after the minimum fallow). In years with dry autumns, where there is an appreciable risk of crop failure, fallowing for a further year will most likely result in an increase in soil moisture content of at least $27 \mathrm{~mm}$, and a decreased risk of crop failure. It is important to note, however, that this conclusion depends on there being no correlation between the rainfall is successive years. Examination of long-term rainfall records from Zaragoza indicates that this assumption is valid. 


\section{Acknowledgements}

We are grateful to our colleagues J.-L. Arrúe and C. Cantero Martinez for their constructive comments during the course of this study and to A. Martínez Cob for obtaining climatic data for Montañana, Candasnos, Daroca, Monflorite, El Canós and Cordoba. 


\section{References}

Allen, R. G., Smith, M., Pereira, L. S. and Perrier, A., 1994. An update for the calculation of reference evapotranspiration. ICID Bulletin 1994, Vol. 43(2) :35- ?.

Amir, J. and Sinclair, T.R., 1996. A straw mulch system to allow continuous wheat production in an arid climate. Field Crops Res., 47:21-31.

Boast, C. W. and Robertson, T. M., 1982. A "Micro-Lysimeter" method for determining evaporation from bare soil: Description and laboratory evaluation. Soil Sci. Soc. Amer. J., 46:689-696.

Bussière, F. and Cellier, P., 1994. Modification of the soil temperature and water content regimes by a crop residue mulch : experiment and modelling. Agric. For. Meteorol., $68: \mid-28$.

Brooks, R. H. and Corey A. T. 1966. Properties of porous media affecting fluid flow. Proc. Am. Soc. Civ. Eng. J., Irrigation Drainage Div., 2:6I-68.

Faci, J. M., Martínez-Cob, A. and Cabezas, A., 1994. Agroclimatología de los regadíos del bajo Gállego: Doce años de observaciones diarias en Montañana (Zaragoza). Dipuación General de Aragón. Departamento de Agricultura, Ganadería y Montes, Zaragoza. pp. 231 .

French, R. J., 1978. The effect of fallowing on the yield of wheat. I. The effect of soil water storage and nitrate supply. Aust. J. agric. Res., 29(4): 653-685.

Gardner, H. R., 1983. Soil properties and efficient water use : Evaporation of water from bare soil. In : H.M. Taylor, W.R. Jordan and T.R. Sinclair (eds) Limitations to efficient water use in crop production. ASA-CSSA-SSSA pP 65-7I. Madison, USA. 
Geng, S., Penning de Vries, F. W. T. and Supit, I., 1986. A simple method for generating daily rainfall data. Agric. For. Meterol., 36: 363-376.

Janssen, B. H., 1972. The significance of the fallow year in the dry farming systems of the Great Konya Basin, Turkey. Neth. J. agric. Sci., 20 : 247-260.

Larney F.J., Lindwall, C.W., 1995. Rotation and tillage effects on available soil water for winter wheat in a semi-arid environment. Soil Tillage Res., 36(3-4): I I I-I 27.

Lawrence, P.A., Radford, B.J., Thomas, G. A., Sinclair, D. P. and Key, A. J., 1994. Effect of tillage practices on wheat performance in a semi-arid environment. Soil Tillage Res., 28:347-364.

López, M. V., Arrúe, J. L., Sánchez-Girón, V., 1996. A comparison between seasonal changes in soil water storage and penetration resistance under conventional and conservation tillage systems in Aragon. Soil Tillage Res., 37: 25I-27I.

López, J. J. and Giráldez, J. V., 1992. ¿Es el barbecho necesario? Análisis de la eficiencia del barbecho mediante un modelo de la evolución de la humedad del suelo. Inv. Agr., Prod. Prot. Veg., 3: 327-343.

López-Fando, C. and Bello, A., 1995. Variability in soil nematode populations due to tillage and crop rotatio in semi-arid Mediterranean agrosystems. Soil Tillage Res., 36:59-72.

Perroux, K. M. and White, I., 1988. Designs for disc permeameters. Soil Sci. Soc. Am. J., 52:1205-12I5.

Radford, B. J., Gibson, G., Nielsen, R. G. H., Butler, D. G., Smith, G. D. and Orange, D.N., 1992. Fallowing practices, soil water storage, plant-available soil nitrogen accumulation and wheat performance in South West Queensland. Soil Tillage Res., 22:73-93. 
Ramig, R.E., Allmaras, R.R. and Papendick, R.I., 1983. Water Conservation: Pacific Northwest. In: H.E. Dregne and W.O. Willis (eds) Dryland agriculture. Agronomy Monograph no. 23, ASA-CSSA-SSSA, Madison, Wisconsin, Pp I05-I 24.

Selker, J. S. and Haith, D. A., 1990. Development and testing of single-parameter precipitation distributions. Water Resources Res., 26: 2733-2740

Unger, P. W., 198I. Tillage effects on wheat and sunflower grown in rotation. Soil Science Society of America Journal., 45:94I-945. 
Table I.

Mean precipitation and evapotranspiration (ETo) of the climatic sites.

\begin{tabular}{llcr}
\hline Region & Location & $\begin{array}{c}\text { Mean Precipitation } \\
\left(\mathrm{mm} \mathrm{year}^{-1}\right)\end{array}$ & $\begin{array}{c}\text { Mean ETo }(\mathrm{mm} \\
\text { year }\end{array}$ \\
Aragón & Candasnos & 362 & $\mathrm{I}, 100$ \\
Cataluña & El Canós & 440 & $\mathrm{I}, 154$ \\
Aragón & Daroca & 456 & 924 \\
Aragón & Monflorite & 485 & 1,162 \\
Aragón & Montañana & 326 & $1,111 \mathrm{I}$ \\
\hline Andalucía & Córdoba & 635 & $\mathrm{I}, 1 \mathrm{II}$ \\
\hline
\end{tabular}


Table 2 .

Soil physical parameters of the selected soils : effective depth, sampling depth, layer thickness, saturated hydraulic conductivity $\left(K_{s}\right)$, saturated volumetric water content $\left(\theta_{s}\right)$, residual saturation $\left(S_{r}\right)$, pore distribution coefficient $(m)$ and bubbling pressure $\left(P_{b}\right)$.

\begin{tabular}{|c|c|c|c|c|c|c|c|c|}
\hline Soil & $\begin{array}{l}\text { Effective depth } \\
\qquad(\mathrm{mm})\end{array}$ & $\begin{array}{l}\text { Sampling depth } \\
\qquad(\mathrm{mm})\end{array}$ & $\begin{array}{l}\text { Layer thickness } \\
\qquad(\mathrm{mm})\end{array}$ & $\begin{array}{c}\mathrm{K}_{0} \\
\left(\mathrm{~mm} \text { day }^{-1}\right)\end{array}$ & $\begin{array}{l}\theta_{s} \\
-\end{array}$ & $\begin{array}{l}\mathrm{Sr} \\
-\end{array}$ & $\begin{array}{l}\mathrm{m} \\
-\end{array}$ & $\begin{array}{c}\mathrm{P}_{\mathrm{b}} \\
(\mathrm{mm})\end{array}$ \\
\hline & & $0-450$ & 50 & $4 \mid 4$ & 0.36 & 0.14 & 0.201 & -408 \\
\hline \multirow[t]{3}{*}{ Vedado } & $\mathrm{I}, 000$ & $450-1200$ & 50 and 100 & 283 & 0.39 & 0.16 & 0.330 & $-1,385$ \\
\hline & & $1200-1300$ & 100 & 269 & 0.41 & 0.15 & 0.226 & $-1,093$ \\
\hline & & $0-150$ & 50 & 30.7 & 0.31 & 0.15 & 0.462 & $-1,139$ \\
\hline \multirow[t]{2}{*}{ EEAD } & 1,000 & $150-450$ & 50 & 41.6 & 0.36 & 0.15 & 0.525 & $-1,469$ \\
\hline & & $450-1200$ & 100 & 96.4 & 0.41 & 0.14 & 0.544 & $-1,3 \mid 5$ \\
\hline \multirow[t]{2}{*}{ Canós UP } & 350 & $0-350$ & 50 & 2,592 & 0.45 & 0.08 & 0.198 & -352 \\
\hline & & $0-300$ & 50 & 793 & 0.61 & 0.11 & 0.205 & -103 \\
\hline \multirow{2}{*}{ Canós LO } & 1,000 & $300-600$ & 50 & 255 & 0.59 & 0.12 & 0.219 & -208 \\
\hline & & $600-1200$ & 100 & 298 & 0.60 & 0.12 & 0.222 & -166 \\
\hline
\end{tabular}


Table 3.

Characteristics of the rainfall for four contrasting sites. Actual values in upper rows. Simulated values in lower rows. All simulations are averages for 25 years.

\begin{tabular}{|c|c|c|c|c|c|c|c|c|c|c|c|c|c|c|}
\hline \multirow{2}{*}{$\begin{array}{c}\text { Location } \\
\text { (time series) }\end{array}$} & \multicolumn{7}{|c|}{$\%$ of days with rain in class $(\mathrm{mm})$} & \multicolumn{6}{|c|}{$\%$ of rain in storms of class $(\mathrm{mm})$} & \multirow{2}{*}{$\begin{array}{c}\text { Actual rainfall } \\
(\mathrm{mm})\end{array}$} \\
\hline & None & $0-2$ & $2-4$ & $4-8$ & $8-16$ & $16-32$ & $>32$ & $0-2$ & $2-4$ & $4-8$ & $8-16$ & $16-32$ & $>32$ & \\
\hline Montañana & 83.6 & 6.8 & 3.3 & 2.7 & 2.2 & 1.0 & 0.3 & 9.1 & 12.4 & 18.3 & 27.9 & 22.4 & 9.8 & 326 \\
\hline (ca. |98I-1992) & 84.3 & 6.4 & 2.7 & 2.9 & 2.4 & 1.0 & 0.3 & 5.6 & 9.1 & 19.0 & 30.7 & 24.3 & 11.2 & 323 \\
\hline Daroca & 76.3 & 10.6 & 4.8 & 4.3 & 2.9 & 1.4 & 0.2 & 8.7 & 12.2 & 20.2 & 26.0 & 23.0 & 9.0 & 456 \\
\hline (ca. 1909-1992) & 76.6 & 9.9 & 4.1 & 4.0 & 3.7 & 1.3 & 0.3 & 6.4 & 9.7 & 18.5 & 34.0 & 23.3 & 8.2 & 452 \\
\hline Monflorite & 76.5 & II.I & 3.1 & 3.9 & 3.3 & 1.7 & 0.4 & 7.2 & 7.1 & 19.3 & 28.1 & 27.1 & 11.3 & 485 \\
\hline (ca. 1975-1992) & 76.6 & 9.2 & 4.0 & 4.3 & 3.8 & 1.6 & 0.4 & 5.5 & 8.4 & 17.8 & 30.5 & 24.9 & 12.8 & 509 \\
\hline Córdoba & 81.2 & 4.9 & 3.2 & 4.1 & 3.5 & 2.3 & 0.7 & 3.0 & 5.7 & 14.8 & 24.0 & 31.3 & 21.0 & 635 \\
\hline (ca. I953-1986) & 81.0 & 5.8 & 3.0 & 3.4 & 3.6 & 2.4 & 0.1 & 2.8 & 5.0 & II.2 & 23.9 & 30.6 & 26.5 & 630 \\
\hline
\end{tabular}


Table 4.

Fitted values of the parameters of the Gompertz equation corresponding to the BA, SL, SH and CR soil surface treatments.

\begin{tabular}{lccc}
\hline Surface Condition & PI & P2 & P3 \\
\hline BA (bare) & 1.267 & 0.1469 & 12.85 \\
SL (30\% stoniness) & 1.102 & 0.1228 & 20.44 \\
SH (60\% stoniness) & 1.133 & 0.1669 & 14.59 \\
CR (Crop residues) & 1.077 & 0.1792 & 17.42 \\
\hline
\end{tabular}


Table 5.

Simulated rainfall $(\mathrm{mm})$ and calculated water contents $(\mathrm{mm})$ of the soil profiles' one year before sowing on I December (i.e. after the minimum 5 month fallow). Results are averages for 25 runs \pm standard deviation.

\begin{tabular}{lccccc}
\hline & \multicolumn{4}{c}{ Climate (Simulated rainfall) } \\
& El Canós & Montañana & Candasnos & Monflorite & Daroca \\
& $(445 \pm 82)$ & $(337 \pm 74)$ & $(363 \pm 82)$ & $(507 \pm 82)$ & $(461 \pm 85)$ \\
\hline Soil $^{2}$ & $153 \pm 16$ & $148 \pm 17$ & $144 \pm 19$ & $171 \pm 24$ & $155 \pm 17$ \\
\hline Vedado(I42) & $131 \pm 20$ & $122 \pm 21$ & $116 \pm 24$ & $141 \pm 28$ & $132 \pm 21$ \\
EEAD (83) & $196 \pm 17$ & $193 \pm 18$ & $195 \pm 23$ & $208 \pm 29$ & $198 \pm 19$ \\
Canós LO (195) & $54 \pm 8$ & $53 \pm 9$ & $49 \pm 10$ & $58 \pm 10$ & $56 \pm 8$ \\
Canós UP (54) & & & &
\end{tabular}

' depth of profiles $1000 \mathrm{~mm}$, except for Canos UP, which was $350 \mathrm{~mm}$ deep.

2 assumed water content at the start of simulation on I July is given in parenthesis. 
Table 6

Calculated water stored $(\mathrm{mm})$ in the profiles during the one year before sowing on I December. Results are averages for 25 runs \pm standard deviation.

\begin{tabular}{lccccc}
\hline & & \multicolumn{5}{c}{ Climate } \\
Soil & El Canós & Montañana & Candasnos & Monflorite & Daroca \\
Vedado & $14 \pm 24$ & $15 \pm 24$ & $13 \pm 21$ & $7 \pm 26$ & $16 \pm 25$ \\
EEAD & $30 \pm 28$ & $33 \pm 29$ & $30 \pm 25$ & $32 \pm 36$ & $33 \pm 30$ \\
Canós LO & $31 \pm 27$ & $25 \pm 31$ & $32 \pm 24$ & $48 \pm 39$ & $44 \pm 27$ \\
Canós UP & $2 \pm 12$ & $1 \pm 12$ & $1 \pm 11$ & $2 \pm 14$ & $2 \pm 12$ \\
\hline
\end{tabular}


Table 7.

Calculated evaporation $(\mathrm{mm})$ from soil surfaces during the one year before sowing on I December. Results are averages for 25 runs \pm standard deviation.

\begin{tabular}{lccccc}
\hline & \multicolumn{5}{c}{ Climate } \\
\cline { 2 - 5 } Soil & El Canós & Montañana & Candasnos & Monflorite & Daroca \\
\hline Vedado & $394 \pm 63$ & $299 \pm 53$ & $309 \pm 55$ & $422 \pm 43$ & $379 \pm 57$ \\
EEAD & $354 \pm 57$ & $266 \pm 48$ & $275 \pm 50$ & $377 \pm 50$ & $336 \pm 49$ \\
Canós LO & $409 \pm 70$ & $310 \pm 59$ & $320 \pm 65$ & $442 \pm 70$ & $403 \pm 70$ \\
Canós UP & $429 \pm 73$ & $322 \pm 62$ & $347 \pm 72$ & $466 \pm 70$ & $329 \pm 74$ \\
\hline
\end{tabular}


Table 8.

Fate of the rainfall during the fallow period of one year before sowing on I December for the climates at Córdoba (Andalucia) and Monflorite (Aragón). Data are for the Canós LO soil and for a profile $1000 \mathrm{~mm}$ deep and are averages of 25 runs \pm standard deviation.

\begin{tabular}{lcc}
\hline & \multicolumn{2}{c}{ Climate } \\
& Córdoba & Monflorite \\
\hline Rainfall $(\mathrm{mm})$ & $663 \pm 133$ & $507 \pm 82$ \\
Initial water content of soil profile $(\mathrm{mm})$ & $234 \pm 45$ & $208 \pm 29$ \\
Water storage $(\mathrm{mm})$ & $72 \pm 64$ & $48 \pm 39$ \\
Evaporation from soil surface $(\mathrm{mm})$ & $454 \pm 55$ & $442 \pm 70$ \\
Drainage $(\mathrm{mm})$ & $137 \pm 91$ & $17 \pm$ \\
\hline
\end{tabular}


Table 9.

Effects of different soil surface conditions on soil water content 365 days before sowing on I December (START), the water stored during the 365 day period before sowing (STORAGE) and on evaporation from the soil sufrace during the same period (EVAPORATION).

Simulation was performed for the Canós LO soil, a profile $1000 \mathrm{~mm}$ deep, and the climate of Montañana. Results are averages for 25 runs \pm standard deviation.

\begin{tabular}{lccc}
\hline Soil surface condition & $\begin{array}{c}\text { START } \\
(\mathrm{mm})\end{array}$ & $\begin{array}{c}\text { STORAGE } \\
(\mathrm{mm})\end{array}$ & $\begin{array}{c}\text { EVAPORATION } \\
(\mathrm{mm})\end{array}$ \\
BA (bare soil) & $194 \pm 18$ & $25 \pm 31$ & $310 \pm 59$ \\
SH (very stony) & $209 \pm 21$ & $40 \pm 33$ & $290 \pm 59$ \\
SL (stony) & $200 \pm 20$ & $32 \pm 33$ & $302 \pm 56$ \\
CR (straw cover) & $217 \pm 23$ & $48 \pm 36$ & $276 \pm 49$ \\
\hline
\end{tabular}

*BA: bare soil; $\mathrm{SH}: 60 \%$ of surface covered by stones; SL: $30 \%$ of surface covered by stones; CR: crop residues, $2500 \mathrm{~g}$ straw $\mathrm{m}^{-2}$ of soil surface. 
Table 10.

Correlation coefficients between the water stored in the soil profile during the fallow period of 365 days before sowing on I December and the rainfall in each of the 12 months of the fallow. Results are for the climate of Montañana and the soil of Canós LO (profile depth I000 $\mathrm{mm}$ ) and are based on 50 runs.

\begin{tabular}{lccc}
\hline & $\begin{array}{c}\text { Correlation coefficient } \\
\text { (water stored in profile vs rainfall in } \\
\text { given month) }\end{array}$ & $\begin{array}{c}\text { Mean rainfall } \\
(\mathrm{mm})\end{array}$ & $\begin{array}{c}\text { standard deviation of } \\
\text { rainfall }(\mathrm{mm})\end{array}$ \\
Month & 0.659 & 38 & 32 \\
October & 0.446 & 46 & 25 \\
September & 0.174 & 23 & 18 \\
August & 0.044 & 21 & 19 \\
July & 0.161 & 18 & 17 \\
June & -0.065 & 28 & 19 \\
May & -0.016 & 48 & 26 \\
April & 0.075 & 35 & 21 \\
March & -0.215 & 9 & 7 \\
February & 0.059 & 22 & 15 \\
January & 0.166 & 20 & 19
\end{tabular}


35

December

0.152

20

II

Legends for Figures

Fig. I. Characteristics of the rainfall in the sites studied derived from long-term records.
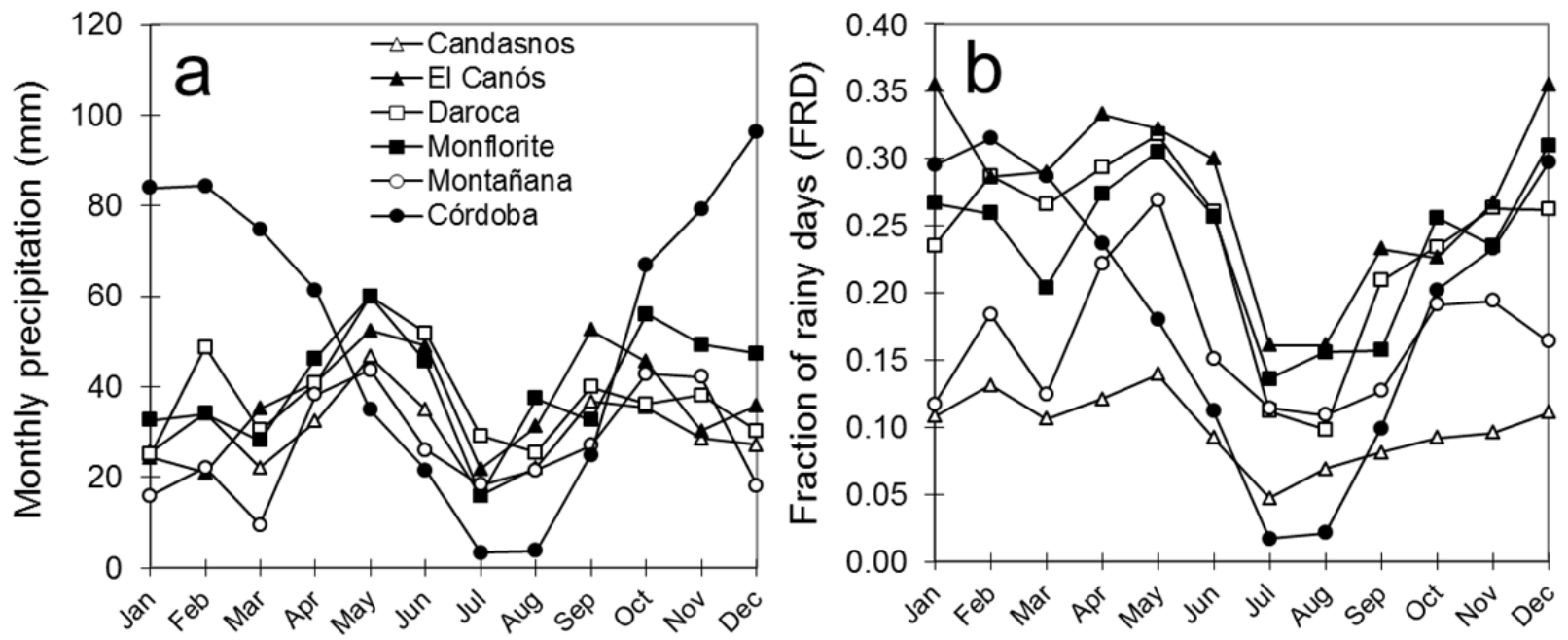
Fig. 2. Relationship between the gravimetric water content $(w)$ of a $5 \mathrm{~cm}$ layer of soil and EETo (the ratio evaporation from the soil surface : reference evapotranspiration). Symbols are for the given soils. The data are for bare soil. The fitted curve (Gompertz equation) is for all data. See text for further explanation

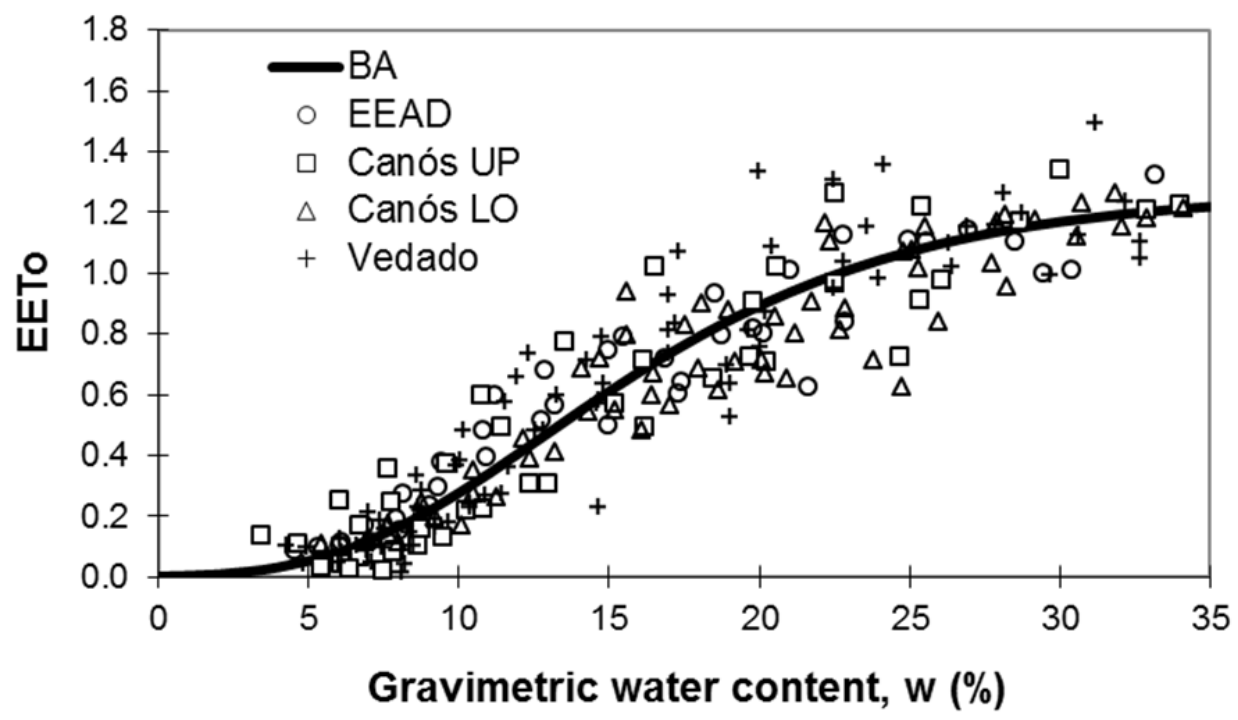


Fig. 3. Fitted Gompertz curves showing the relationship between the gravimetric water content $(w)$ of a $5 \mathrm{~cm}$ layer of soil and EETo, the ratio (evaporation from the soil surface : ETo) for different soil surface conditions. BA, bare soil (the same curve as that shown in Fig. 2.); SL, $30 \%$ of soil surface covered by stones; $\mathrm{SH}, 60 \%$ of soil surface covered by stones; $\mathrm{CR}$, soil covered with $2500 \mathrm{~kg}^{-1} \mathrm{ha}^{-1}$ residues from a barley crop.

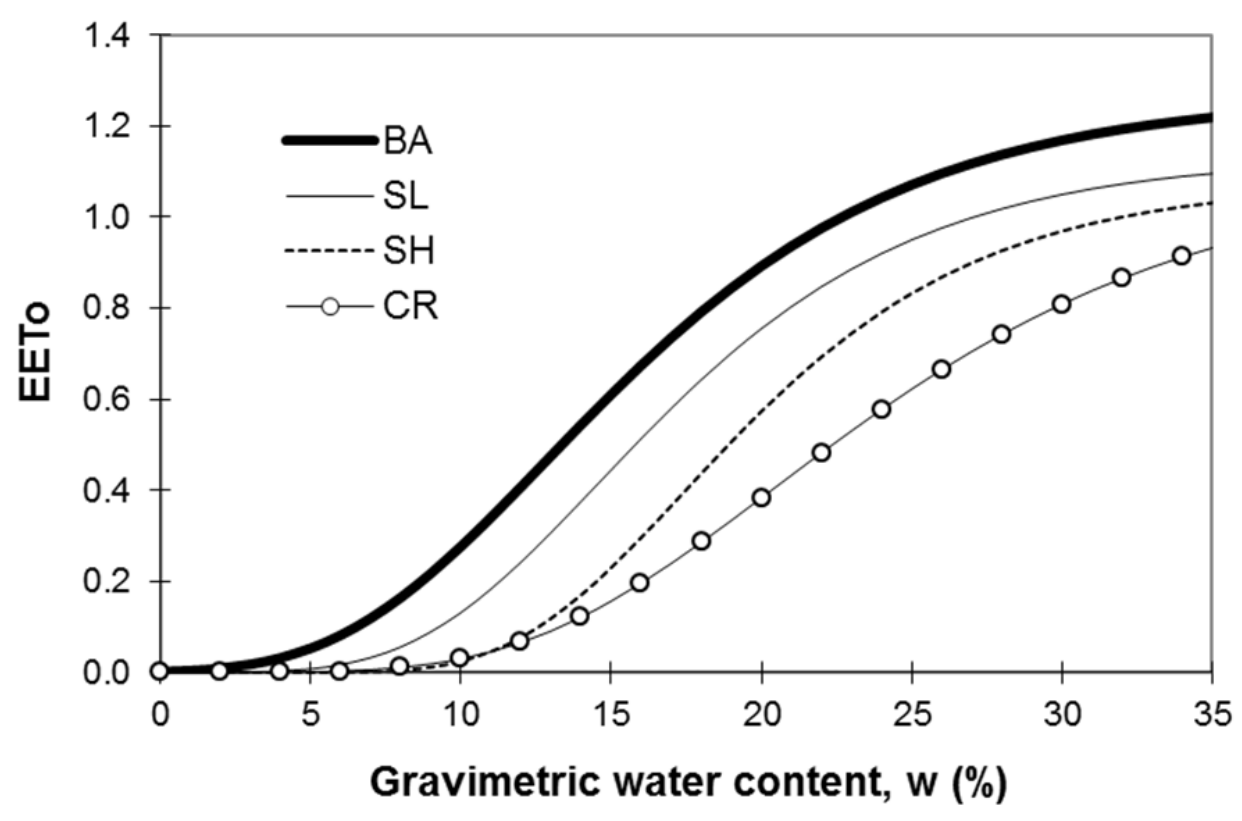


Fig. 4. Calculated water contents $(\mathrm{mm})$ of profile of Canós LO soil to a depth of $1000 \mathrm{~mm}$ at the start of simulation (I June) and on the last day of each subsequent month. Symbols represent means of 25 runs and the bars represent standard deviations.

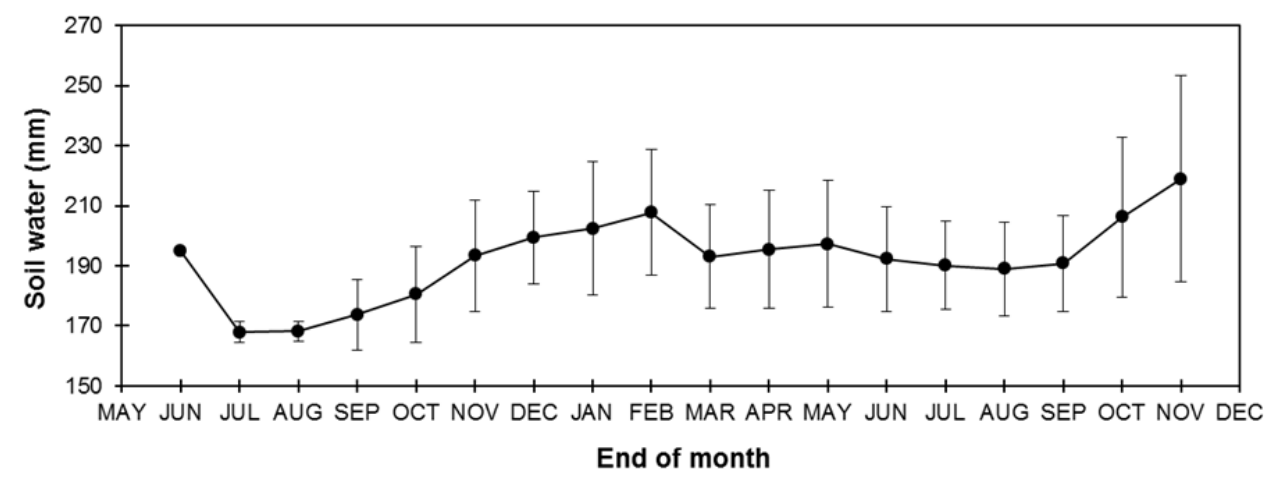


Fig. 5. Relationship between the calculated water stored in the EEAD soil profile to a depth of $1000 \mathrm{~mm}$ (a) during the entire 17 month of the fallow, (b) during the first six months of the last 365 days of the fallow, (c) during the last six months of the last 365 days of the fallow and (d) during the last 365 days of the fallow. Results are for 50 runs with the Montañana climate. 

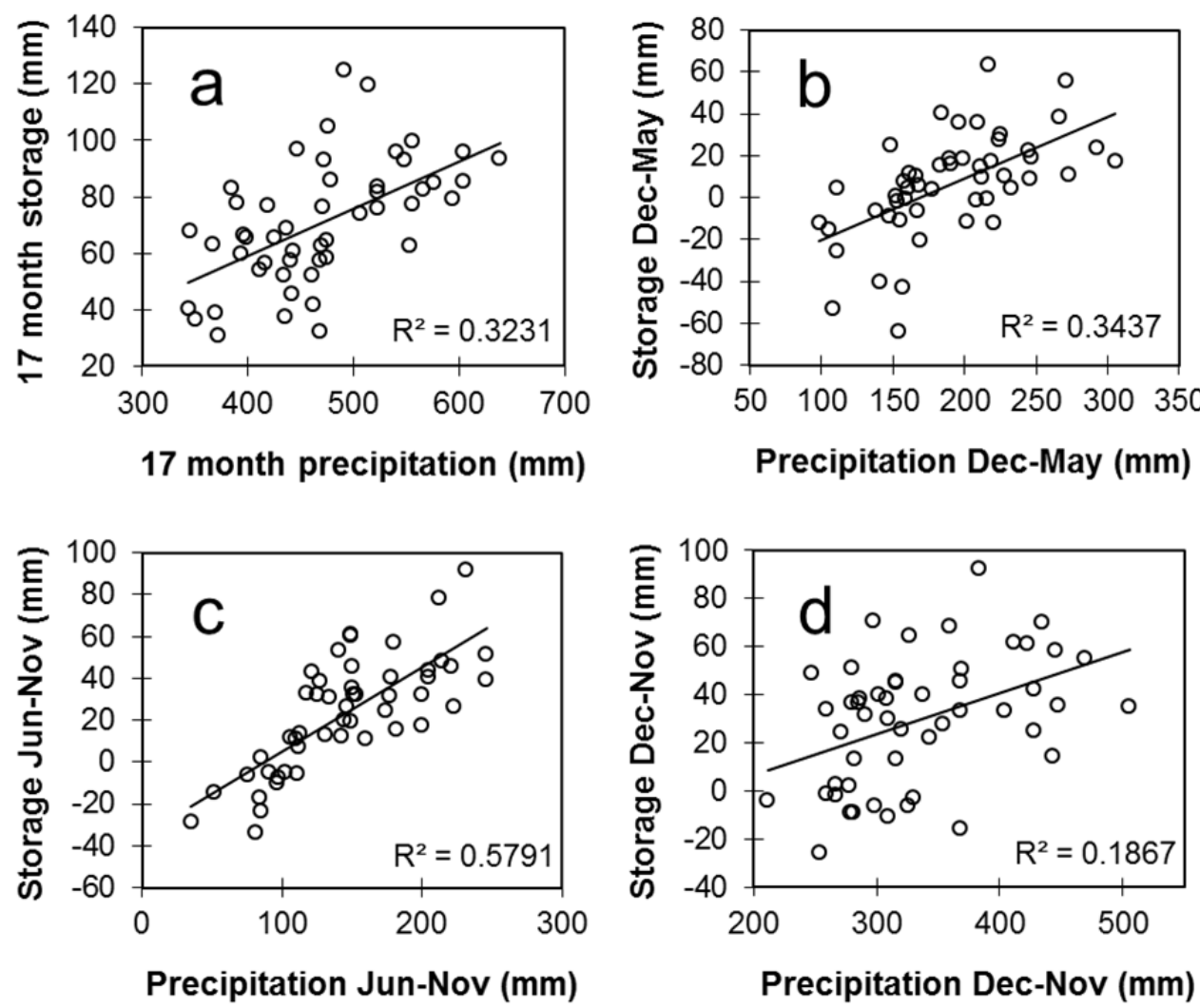
Fig. 6. Soil water profile at days I8I (start of simulation), 334 (365 days before sowing), and 708 (nearly sowing) for the Montañana climate and Canós LO* soil. Data are averages and standard deviations from 25 runs.

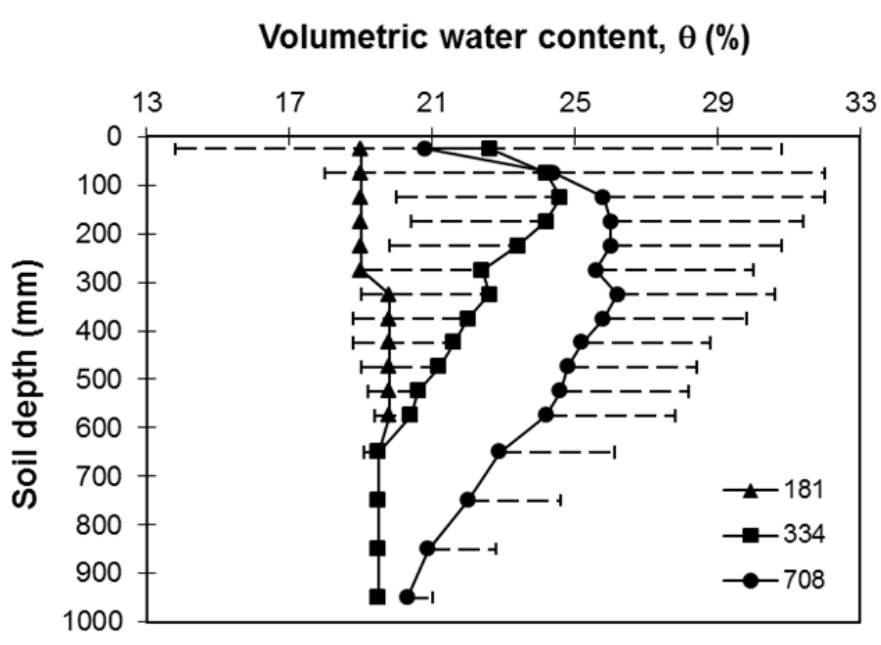

${ }^{*}$ In this soil the approximate volumetric water contents for wilting point and field capacity are $19 \%$ and $52 \%$, respectively.

Table I.

Mean precipitation and evapotranspiration (ETo) of the climatic sites. 


\begin{tabular}{|c|c|c|c|}
\hline Region & Location & $\begin{array}{l}\text { Mean Precipitation } \\
\left(\mathrm{mm} \text { year }^{-1}\right)\end{array}$ & $\begin{array}{l}\text { Mean ETo }(\mathrm{mm} \\
\left.\text { year }^{-1}\right)\end{array}$ \\
\hline Aragón & Candasnos & 362 & 1,100 \\
\hline Cataluña & El Canós & 440 & $\mathrm{I}, 154$ \\
\hline Aragón & Daroca & 456 & 924 \\
\hline Aragón & Monflorite & 485 & 1,162 \\
\hline Aragón & Montañana & 326 & 1,111 \\
\hline Andalucía & Córdoba & 635 & I,III \\
\hline
\end{tabular}


Table 2 .

Soil physical parameters of the selected soils : effective depth, sampling depth, layer thickness, saturated hydraulic conductivity $\left(K_{s}\right)$, saturated volumetric water content $\left(\theta_{s}\right)$, residual saturation $\left(S_{r}\right)$, pore distribution coefficient $(m)$ and bubbling pressure $\left(P_{b}\right)$.

\begin{tabular}{|c|c|c|c|c|c|c|c|c|}
\hline Soil & $\begin{array}{l}\text { Effective depth } \\
(\mathrm{mm})\end{array}$ & $\begin{array}{l}\text { Sampling depth } \\
(\mathrm{mm})\end{array}$ & $\begin{array}{l}\text { Layer thickness } \\
\qquad(\mathrm{mm})\end{array}$ & $\begin{array}{c}\mathrm{K}_{0} \\
\left(\mathrm{~mm} \text { day }^{-1}\right)\end{array}$ & $\begin{array}{l}\theta_{s} \\
- \\
\end{array}$ & $\begin{array}{c}\mathrm{Sr} \\
-\end{array}$ & $\begin{array}{l}m \\
-\end{array}$ & $\begin{array}{c}P_{\mathrm{b}} \\
(\mathrm{mm})\end{array}$ \\
\hline & & $0-450$ & 50 & $4 \mid 4$ & 0.36 & 0.14 & 0.201 & -408 \\
\hline \multirow[t]{3}{*}{ Vedado } & 1,000 & $450-1200$ & 50 and 100 & 283 & 0.39 & 0.16 & 0.330 & $-1,385$ \\
\hline & & $1200-1300$ & 100 & 269 & 0.41 & 0.15 & 0.226 & $-1,093$ \\
\hline & & $0-150$ & 50 & 30.7 & 0.31 & 0.15 & 0.462 & $-1,139$ \\
\hline \multirow[t]{2}{*}{ EEAD } & $\mathrm{I}, 000$ & $150-450$ & 50 & 41.6 & 0.36 & 0.15 & 0.525 & $-1,469$ \\
\hline & & $450-1200$ & 100 & 96.4 & $0.4 I$ & 0.14 & 0.544 & $-1,315$ \\
\hline \multirow[t]{2}{*}{ Canós UP } & 350 & $0-350$ & 50 & 2,592 & 0.45 & 0.08 & 0.198 & -352 \\
\hline & & $0-300$ & 50 & 793 & 0.61 & 0.11 & 0.205 & -103 \\
\hline \multirow[t]{2}{*}{ Canós LO } & 1,000 & $300-600$ & 50 & 255 & 0.59 & 0.12 & 0.219 & -208 \\
\hline & & $600-1200$ & 100 & 298 & 0.60 & 0.12 & 0.222 & -166 \\
\hline
\end{tabular}


Table 3.

Characteristics of the rainfall for four contrasting sites. Actual values in upper rows. Simulated values in lower rows. All simulations are averages for 25 years.

\begin{tabular}{|c|c|c|c|c|c|c|c|c|c|c|c|c|c|c|}
\hline \multirow{2}{*}{$\begin{array}{c}\text { Location } \\
\text { (time series) }\end{array}$} & \multicolumn{7}{|c|}{$\%$ of days with rain in class $(\mathrm{mm})$} & \multicolumn{6}{|c|}{$\%$ of rain in storms of class $(\mathrm{mm})$} & \multirow{2}{*}{$\begin{array}{l}\text { Actual rainfal } \\
(\mathrm{mm})\end{array}$} \\
\hline & None & $0-2$ & $2-4$ & $4-8$ & $8-16$ & $16-32$ & $>32$ & $0-2$ & $2-4$ & $4-8$ & $8-16$ & $16-32$ & $>32$ & \\
\hline Montañana & 83.6 & 6.8 & 3.3 & 2.7 & 2.2 & 1.0 & 0.3 & 9.1 & 12.4 & 18.3 & 27.9 & 22.4 & 9.8 & 326 \\
\hline (ca. 198I-1992) & 84.3 & 6.4 & 2.7 & 2.9 & 2.4 & 1.0 & 0.3 & 5.6 & 9.1 & 19.0 & 30.7 & 24.3 & 11.2 & 323 \\
\hline Daroca & 76.3 & 10.6 & 4.8 & 4.3 & 2.9 & 1.4 & 0.2 & 8.7 & 12.2 & 20.2 & 26.0 & 23.0 & 9.0 & 456 \\
\hline (ca. 1909-1992) & 76.6 & 9.9 & 4.1 & 4.0 & 3.7 & 1.3 & 0.3 & 6.4 & 9.7 & 18.5 & 34.0 & 23.3 & 8.2 & 452 \\
\hline Monflorite & 76.5 & II.I & 3.1 & 3.9 & 3.3 & 1.7 & 0.4 & 7.2 & 7.1 & 19.3 & 28.1 & 27.1 & 11.3 & 485 \\
\hline (ca. 1975-1992) & 76.6 & 9.2 & 4.0 & 4.3 & 3.8 & 1.6 & 0.4 & 5.5 & 8.4 & 17.8 & 30.5 & 24.9 & 12.8 & 509 \\
\hline Córdoba & 81.2 & 4.9 & 3.2 & 4. 1 & 3.5 & 2.3 & 0.7 & 3.0 & 5.7 & 14.8 & 24.0 & 31.3 & 21.0 & 635 \\
\hline (ca. 1953-1986) & 81.0 & 5.8 & 3.0 & 3.4 & 3.6 & 2.4 & 0.1 & 2.8 & 5.0 & II.2 & 23.9 & 30.6 & 26.5 & 630 \\
\hline
\end{tabular}


Table 4

Fitted values of the parameters of the Gompertz equation corresponding to the BA, SL, SH and CR soil surface treatments.

\begin{tabular}{lccc}
\hline Surface Condition & PI & P2 & P3 \\
\hline BA (bare) & 1.267 & 0.1469 & 12.85 \\
SL (30\% stoniness) & 1.102 & 0.1228 & 20.44 \\
SH (60\% stoniness) & 1.133 & 0.1669 & 14.59 \\
CR (Crop residues) & 1.077 & 0.1792 & 17.42 \\
\hline
\end{tabular}


Table 5.

Simulated rainfall $(\mathrm{mm})$ and calculated water contents $(\mathrm{mm})$ of the soil profiles' one year before sowing on I December (i.e. after the minimum 5 month fallow). Results are averages for 25 runs \pm standard deviation.

\begin{tabular}{lccccc}
\hline & \multicolumn{4}{c}{ Climate (Simulated rainfall) } \\
& El Canós & Montañana & Candasnos & Monflorite & Daroca \\
& $(445 \pm 82)$ & $(337 \pm 74)$ & $(363 \pm 82)$ & $(507 \pm 82)$ & $(461 \pm 85)$ \\
\hline Soil $^{2}$ & $153 \pm 16$ & $148 \pm 17$ & $144 \pm 19$ & $171 \pm 24$ & $155 \pm 17$ \\
\hline Vedado(I42) & $131 \pm 20$ & $122 \pm 21$ & $116 \pm 24$ & $141 \pm 28$ & $132 \pm 21$ \\
EEAD (83) & $196 \pm 17$ & $193 \pm 18$ & $195 \pm 23$ & $208 \pm 29$ & $198 \pm 19$ \\
Canós LO (195) & $54 \pm 8$ & $53 \pm 9$ & $49 \pm 10$ & $58 \pm 10$ & $56 \pm 8$ \\
Canós UP (54) & & & &
\end{tabular}

' depth of profiles $1000 \mathrm{~mm}$, except for Canos UP, which was $350 \mathrm{~mm}$ deep.

2 assumed water content at the start of simulation on I July is given in parenthesis. 
Table 6

Calculated water stored $(\mathrm{mm})$ in the profiles during the one year before sowing on I December. Results are averages for 25 runs \pm standard deviation.

\begin{tabular}{lccccc}
\hline & & \multicolumn{5}{c}{ Climate } \\
Soil & El Canós & Montañana & Candasnos & Monflorite & Daroca \\
Vedado & $14 \pm 24$ & $15 \pm 24$ & $13 \pm 21$ & $7 \pm 26$ & $16 \pm 25$ \\
EEAD & $30 \pm 28$ & $33 \pm 29$ & $30 \pm 25$ & $32 \pm 36$ & $33 \pm 30$ \\
Canós LO & $31 \pm 27$ & $25 \pm 31$ & $32 \pm 24$ & $48 \pm 39$ & $44 \pm 27$ \\
Canós UP & $2 \pm 12$ & $1 \pm 12$ & $1 \pm 11$ & $2 \pm 14$ & $2 \pm 12$ \\
\hline
\end{tabular}


Table 7.

Calculated evaporation $(\mathrm{mm})$ from soil surfaces during the one year before sowing on I December. Results are averages for 25 runs \pm standard deviation.

\begin{tabular}{lccccc}
\hline & \multicolumn{5}{c}{ Climate } \\
\cline { 2 - 5 } Soil & El Canós & Montañana & Candasnos & Monflorite & Daroca \\
\hline Vedado & $394 \pm 63$ & $299 \pm 53$ & $309 \pm 55$ & $422 \pm 43$ & $379 \pm 57$ \\
EEAD & $354 \pm 57$ & $266 \pm 48$ & $275 \pm 50$ & $377 \pm 50$ & $336 \pm 49$ \\
Canós LO & $409 \pm 70$ & $310 \pm 59$ & $320 \pm 65$ & $442 \pm 70$ & $403 \pm 70$ \\
Canós UP & $429 \pm 73$ & $322 \pm 62$ & $347 \pm 72$ & $466 \pm 70$ & $329 \pm 74$ \\
\hline
\end{tabular}


Table 8.

Fate of the rainfall during the fallow period of one year before sowing on I December for the climates at Córdoba (Andalucia) and Monflorite (Aragón). Data are for the Canós LO soil and for a profile $1000 \mathrm{~mm}$ deep and are averages of 25 runs \pm standard deviation.

\begin{tabular}{lcc}
\hline & \multicolumn{2}{c}{ Climate } \\
& Córdoba & Monflorite \\
\hline Rainfall $(\mathrm{mm})$ & $663 \pm 133$ & $507 \pm 82$ \\
Initial water content of soil profile $(\mathrm{mm})$ & $234 \pm 45$ & $208 \pm 29$ \\
Water storage $(\mathrm{mm})$ & $72 \pm 64$ & $48 \pm 39$ \\
Evaporation from soil surface $(\mathrm{mm})$ & $454 \pm 55$ & $442 \pm 70$ \\
Drainage $(\mathrm{mm})$ & $137 \pm 91$ & $17 \pm$ \\
\hline
\end{tabular}


Table 9.

Effects of different soil surface conditions on soil water content 365 days before sowing on I December (START), the water stored during the 365 day period before sowing (STORAGE) and on evaporation from the soil sufrace during the same period (EVAPORATION).

Simulation was performed for the Canós LO soil, a profile $1000 \mathrm{~mm}$ deep, and the climate of Montañana. Results are averages for 25 runs \pm standard deviation.

\begin{tabular}{lccc}
\hline Soil surface condition & $\begin{array}{c}\text { START } \\
(\mathrm{mm})\end{array}$ & $\begin{array}{c}\text { STORAGE } \\
(\mathrm{mm})\end{array}$ & $\begin{array}{c}\text { EVAPORATION } \\
(\mathrm{mm})\end{array}$ \\
BA (bare soil) & $194 \pm 18$ & $25 \pm 31$ & $310 \pm 59$ \\
SH (very stony) & $209 \pm 21$ & $40 \pm 33$ & $290 \pm 59$ \\
SL (stony) & $200 \pm 20$ & $32 \pm 33$ & $302 \pm 56$ \\
CR (straw cover) & $217 \pm 23$ & $48 \pm 36$ & $276 \pm 49$ \\
\hline
\end{tabular}

*BA: bare soil; $\mathrm{SH}: 60 \%$ of surface covered by stones; SL: $30 \%$ of surface covered by stones; CR: crop residues, $2500 \mathrm{~g}$ straw $\mathrm{m}^{-2}$ of soil surface. 
Table 10.

Correlation coefficients between the water stored in the soil profile during the fallow period of 365 days before sowing on I December and the rainfall in each of the 12 months of the fallow. Results are for the climate of Montañana and the soil of Canós LO (profile depth 1000 $\mathrm{mm}$ ) and are based on 50 runs.

\begin{tabular}{lccc}
\hline & $\begin{array}{c}\text { Correlation coefficient } \\
\text { (water stored in profile vs rainfall in } \\
\text { given month) }\end{array}$ & $\begin{array}{c}\text { Mean rainfall } \\
(\mathrm{mm})\end{array}$ & $\begin{array}{c}\text { standard deviation of } \\
\text { rainfall }(\mathrm{mm})\end{array}$ \\
Month & 0.659 & 38 & 32 \\
November & 0.446 & 46 & 25 \\
October & 0.174 & 23 & 18 \\
September & 0.044 & 21 & 19 \\
Jugust & 0.161 & 18 & 17 \\
June & -0.065 & 28 & 19 \\
May & -0.016 & 48 & 26 \\
April & 0.075 & 35 & 21 \\
March & -0.215 & 9 & 7 \\
February & 0.059 & 22 & 15 \\
January & 0.166 & 20 & 19
\end{tabular}


53

Legends for Figures

Fig. I. Characteristics of the rainfall in the sites studied derived from long-term records.
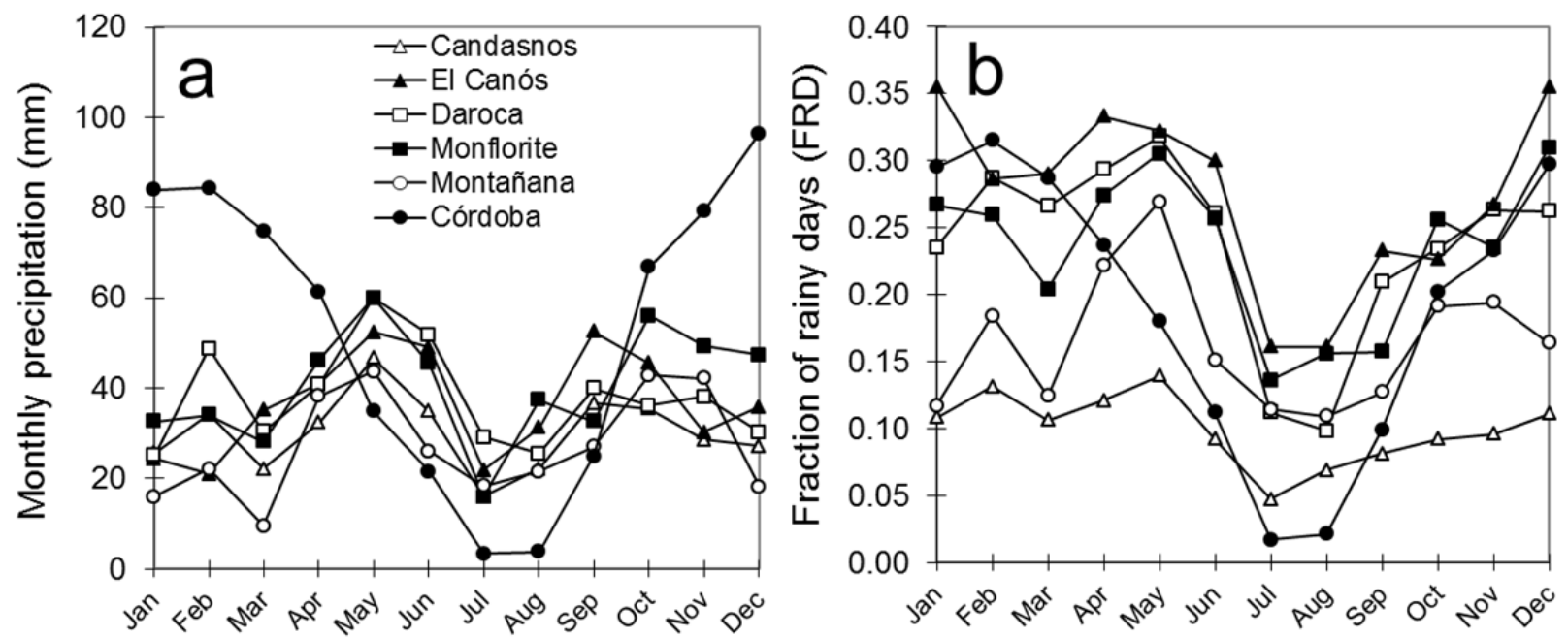
Fig. 2. Relationship between the gravimetric water content $(w)$ of a $5 \mathrm{~cm}$ layer of soil and EETo (the ratio evaporation from the soil surface : reference evapotranspiration). Symbols are for the given soils. The data are for bare soil. The fitted curve (Gompertz equation) is for all data. See text for further explanation

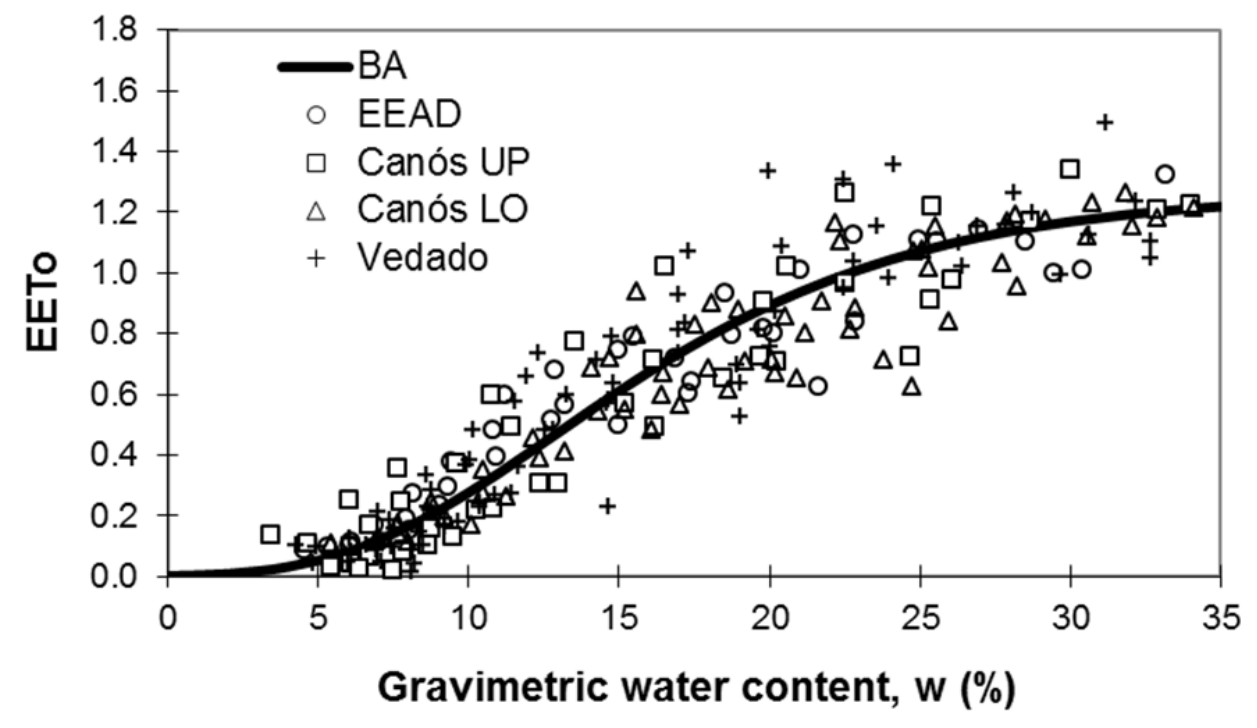


Fig. 3. Fitted Gompertz curves showing the relationship between the gravimetric water content $(w)$ of a $5 \mathrm{~cm}$ layer of soil and EETo, the ratio (evaporation from the soil surface : ETo) for different soil surface conditions. BA, bare soil (the same curve as that shown in Fig. 2.); SL, 30 \% of soil surface covered by stones; $\mathrm{SH}, 60 \%$ of soil surface covered by stones; CR, soil covered with $2500 \mathrm{~kg} \mathrm{ha}^{-1}$ of residues from a barley crop.

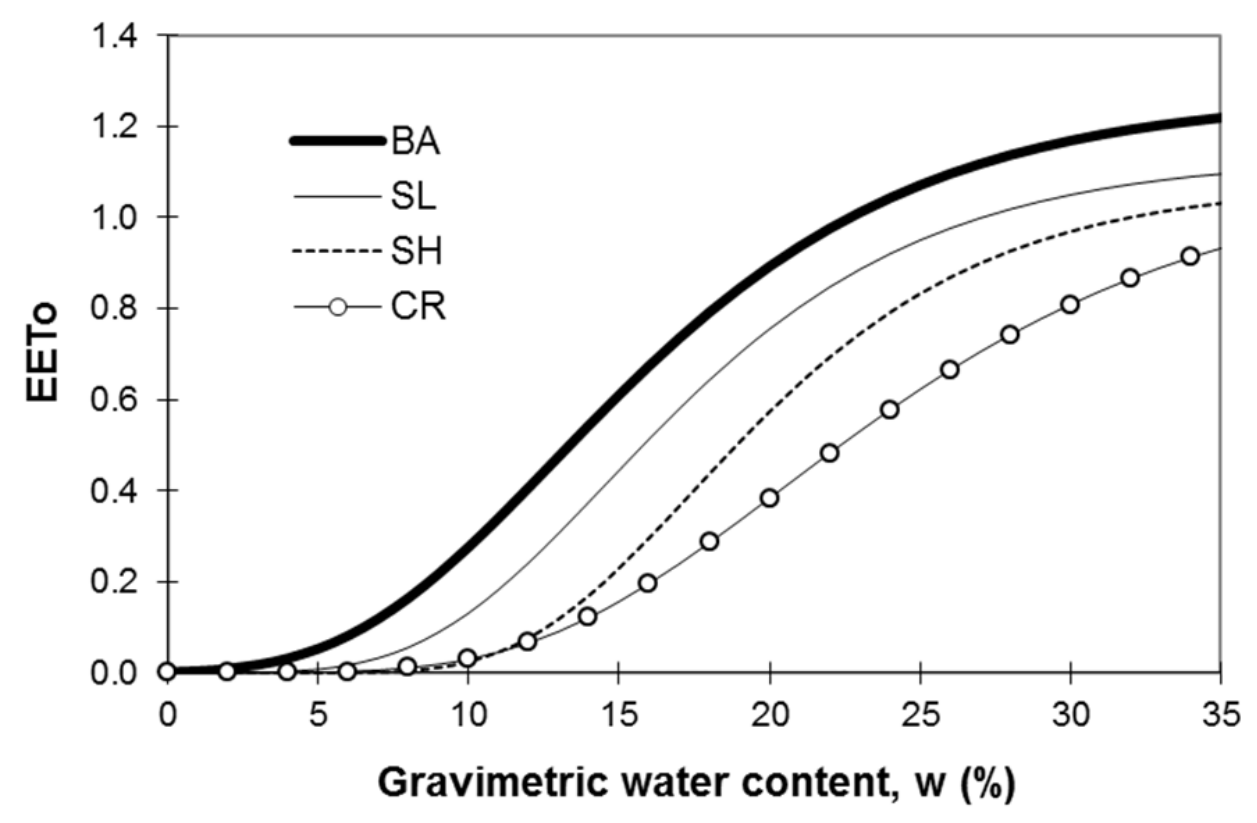


Fig. 4. Calculated water contents $(\mathrm{mm})$ of profile of Canós LO soil to a depth of $1000 \mathrm{~mm}$ at the start of simulation (I June) and on the last day of each subsequent month. Symbols represent means of 25 runs and the bars represent standard deviations.

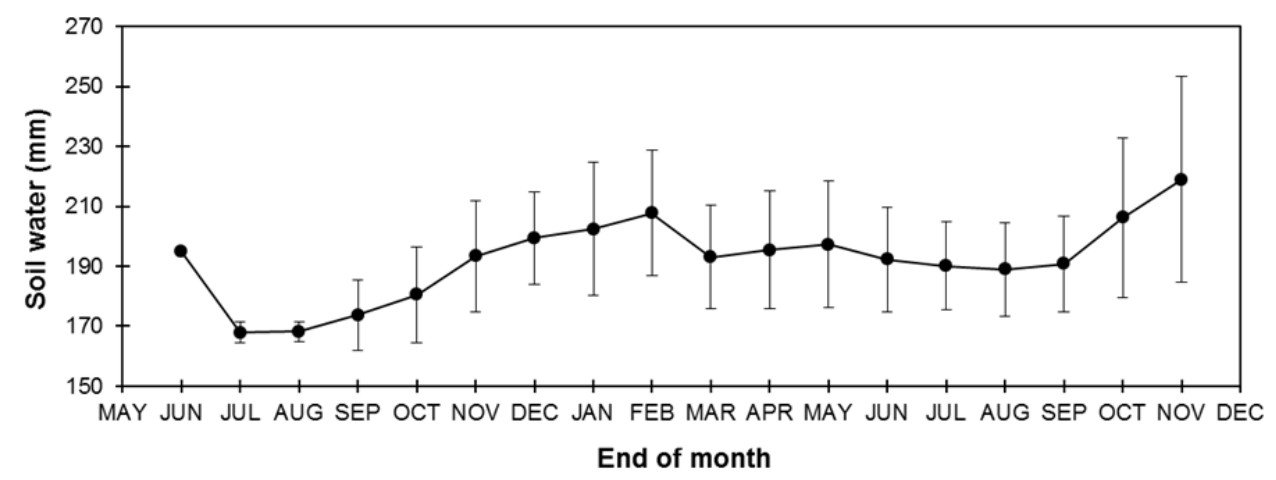


Fig. 5. Relationship between the calculated water stored in the EEAD soil profile to a depth of $1000 \mathrm{~mm}$ (a) during the entire 17 month of the fallow, (b) during the first six months of the last 365 days of the fallow, (c) during the last six months of the last 365 days of the fallow and (d) during the last 365 days of the fallow. Results are for 50 runs with the Montañana climate.

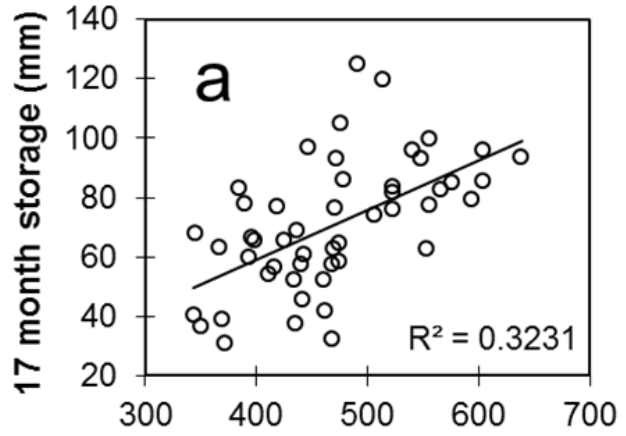

17 month precipitation $(\mathrm{mm})$

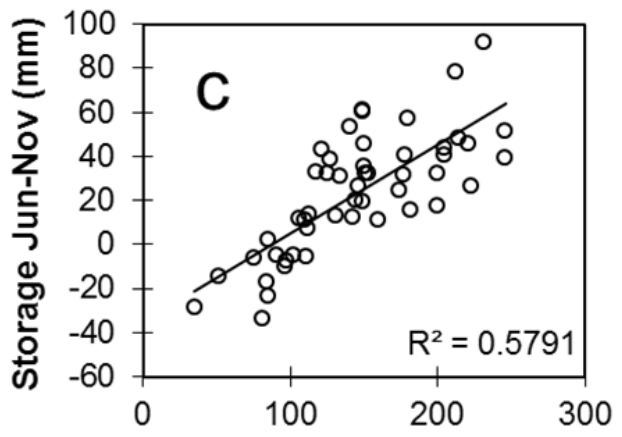

Precipitation Jun-Nov (mm)

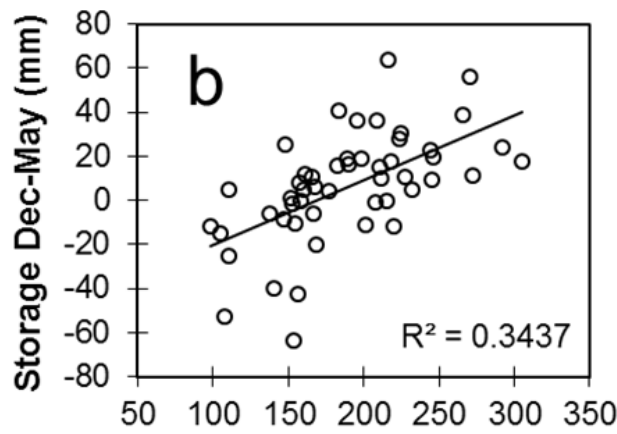

Precipitation Dec-May (mm)

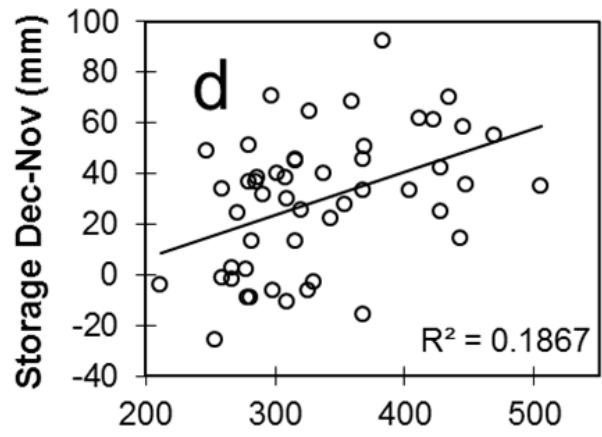

Precipitation Dec-Nov (mm) 
Fig. 6. Soil water profile at days I8I (start of simulation), 334 (365 days before sowing), and 708 (nearly sowing) for the Montañana climate and Canós LO* soil. Data are averages and standard deviations from 25 runs.

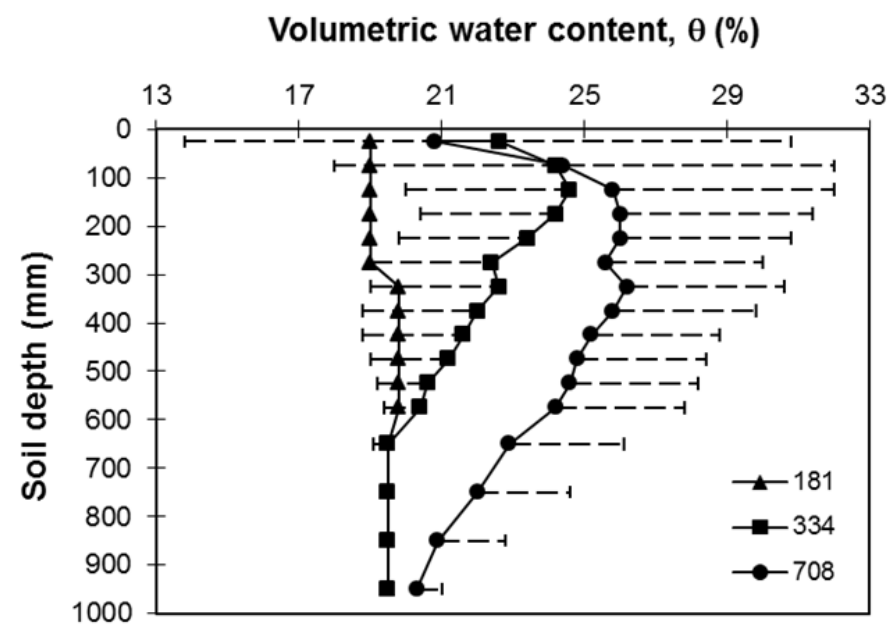

* In this soil the approximate volumetric water contents for wilting point and field capacity are $19 \%$ and $52 \%$, respectively. 